\title{
PEDAGOGIA DA AUTONOMIA: SABERES NECESSÁRIOS À PRÁTICA EDUCATIVA.
}

FREIRE, Paulo. Pedagogia da autonomia: saberes necessários à prática

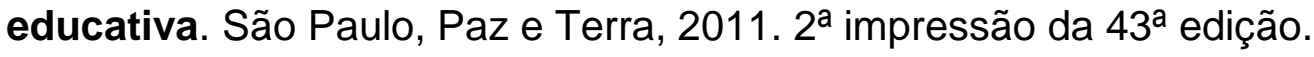

MATIAS, Carlos dos Passos Paulo ${ }^{1}$

Insignare do latim é fazer sinal. Ensinar, então, pode ser pensado como a capacidade de fazer o maior número de sinais possíveis; o domínio mais abrangente possível de saberes que se fazem imprescindíveis na prática educativa. Nesta magistral obra, Paulo Freire nos brinda, de forma crítica e reflexiva, com uma abrangente discussão sobre saberes que todo educador tem o dever ético de não ignorar, sob pena de "depor" contra a própria prática, a boniteza séria e ao mesmo tempo alegre, comprometida, política, moral e humanizada de uma educação que seja de fato transformadora da realidade e inspiradora/renovadora da esperança naquilo que nós humanos temos de mais sublime: a eterna autoconstrução, pois "formar é muito mais do que puramente treinar o educando no desempenho de destrezas" (p.16).

Publicado, a edição em apreço, no ano de 2011 pela Editora Paz e Terra, a obra está dividida em três partes: 1) Prática docente: primeiras palavras; 2) Ensinar não é transmitir conhecimento e 3) Ensinar é uma especialidade humana. $\mathrm{O}$ autor com uma elegante eloquência convida/leva o leitor a pensar e repensar, contextos políticos e econômicos que de forma direta ou indireta têm influenciado a prática educativa em nossa sociedade. Sociedade esta que desde sempre carece de reflexões éticas e morais. Não porque não tenha, mas porque se não pensar, se não refletir sobre suas ações, suas práticas, suas contradições, suas "discórdias", suas fraquezas, erros e acertos, não conseguirá, de forma verdadeira, dialogar com seus iguais e seus desiguais, com coragem, com seriedade, com responsabilidade, comprometimento e respeito, e isto pode ser um dos sérios entraves a nossa tão sonhada

${ }^{1}$ Carlos dos Passos Paulo Matias. Graduado em História e Mestre em Educação pela UNESC Universidade do Extremo Sul Catarinense. Professor de História do Instituto Federal de Santa Catarina IFSC - Câmpus Caçador.

Criar Educação, Criciúma, v. 6, ํ1, julho/novembro 2016.- PPGE - UNESC 
educação de qualidade. "Posso não aceitar a concepção pedagógica deste ou daquela autora, e devo inclusive expor aos alunos as razões por que me oponho a ela, mas o que não posso, na minha crítica, é mentir" (p.18).

Freire, fazendo uma crítica ao modelo neoliberal, a uma ideologia fatalista em relação às potencialidades humanas, a educação insossa, procura encorajar o educador a reflexão crítica sobre a prática docente. Faz o professor perceberse sujeito da história, sujeito da própria vida. Mas, não só o professor. Talvez aqui o mais desafiador da docência, Freire chama o professor para acreditar em seu potencial e conseguir fazer o aluno acreditar neste potencial, que não é exclusivo do professor e/ou do aluno, é humano, é universal é de gente, "ensinar não é transmitir conhecimento, mas criar as possiblidades para a sua produção ou sua construção" (p.24).

Paulo Freire coloca o leitor e pensar, não só sobre a educação formal, a educação institucionalizada, mas na beleza das relações humanas. $\mathrm{Na}$ vida como potência de mudança. Na existência humana como processo de construção sempre inacabado. E não inacabado como impotência ou fatalismo; inacabado porque a beleza do conhecer, do aprender/ensinar, é um processo gostoso, maravilhoso, desafiador, necessário e possível. "Foi assim, socialmente aprendendo, que ao longo dos tempos mulheres e homens perceberam que era possível - depois, preciso - trabalhar maneiras, caminhos, métodos de ensinar" (p.26). Quando esta percepção é alcançada, o autor nos conduz a idealização de que a prática educativa é uma prática política. Fazemos educação contextualizada com nosso bairro, nossa cidade, nosso país, nossos problemas... Nossa prática passa a ser progressista e históricocrítica. Superar o fatalismo neoliberal, as práticas reacionárias, muitas vezes antiéticas, os ranços do tradicional, enfim, ser livre, ter a coragem da liberdade, do pensamento correto, pode ser a forma mais eficiente e mais concreta de ruptura. A prática docente, o processo de educar é por caraterística própria uma prática que tem apetência pela curiosidade, pensa na curiosidade, busca a curiosidade, no entanto esta curiosidade, nos alerta o autor, pode ser ingénua, pode ser no senso comum. Não é o que se espera de um educador, ao menos 
o educador comprometido. Logo, "a superação e não a ruptura se dá na medida em que a curiosidade ingênua, sem deixar de ser curiosidade, pelo contrário, continuando a ser curiosidade, se criticiza” (p.32). Destarte este pensamento quando crítico, político, racional, comprometido, corajoso e belo, nos diz o autor, forçosamente vai concretizar-se num pensar coerente, correto. E assim, faremos e teremos educadores num clima de criação, de educação para todos, por todos. Um diálogo de igual para igual, um ambiente de compreensão, uma prática educativa que ultrapassa possíveis interesses ideológicos, mesmo sendo a educação uma ação política, pois predominará uma ética humana, uma relação necessária entre os seres humanos. "O clima de que pensa certo é o de quem busca seriamente a segurança na argumentação, é o de quem, discordando do seu oponente, não tem por que contra ele ou contra ela nutrir uma raiva desmedida, bem maior, às vezes, do que a razão mesma da discordância" (p.36). Freire termina a primeira parte nos mostrando que pensar certo não tem muito sentido, ou não tem sentido, se a ação, a prática, a postura do educador não for coerente. Pois pensar certo requer agir certo. Pensar certo é assumir de forma verdadeira, corajosa e imediata a ação correta, a ideia correta, a vida plena, "o pensar certo, por isso, é dialógico e não polêmico" (p.38).

Na segunda parte da obra Paulo Freire insiste na questão tão cara a sua luta como educador. A de que ensinar não é transmissão de conhecimento pura e simplesmente. "É preciso insistir: este saber necessário ao professor - de que ensinar não é transferir conhecimento" (p.47). Ter, o educador, a clareza dos fundamentos filosóficos da educação; a compreensão das complexas relações humanas em várias formas de organizações sociais; compreender a dialética existencial, tudo contribui para que o professor educador enriqueça sua prática partindo do pressuposto de que o ser humano não nasce humano, torna-se humano. Logo, estamos inacabados. Esta compreensão é para Paulo Freire uma questão ética. Quão importante se torna ter, o educador, uma postura livre para a mudança. Posto nossa inquietude é permanente, buscamos algo melhor, vida melhor, relações mais igualitárias, democráticas, mais humanas. Sabemos consciente ou inconsciente, que podemos ser melhores. O educador Criar Educação, Criciúma, v. 6, nº1, julho/novembro 2016.- PPGE - UNESC 
comprometido sabe e acredita que seus alunos, sua aluna, podem ser melhores. Os políticos sabem que a vida em sociedade pode ser melhor. Os líderes espirituais também não ignoram esta potência humana. Vir a ser é o nosso grande caminho da felicidade, da igualdade, da vida plena. "Aqui chegamos ao ponto de que talvez devêssemos ter partido. $\mathrm{O}$ do inacabamento do ser humano. Na verdade, o inacabamento do ser ou sua inconclusão é próprio da experiência vital" (p.50). Freire leva o leitor, educador ou não, a questionar-se sobre sua participação ativa nas transformações ou permanências das coisas relativas às relações sociais, políticas, econômicas... O autor avança e insiste na ideia de é gostoso ser gente, pois mesmo condicionado, isso pode ser possível em diversas ocasiões, também é verdade que se pode ir além do condicionamento. "Sei que as coisas podem até piorar, mas sei também que é possível intervir para melhorá-las" (p.52). Assim, Paulo Freire brinda-nos com saberes que não podemos ignorar de forma alguma enquanto educadores. Coloca-nos na condição de sujeito histórico. Importante questão para quem vai inspirar pessoas. Pois é sentindo-se histórico que podemos perceber nosso tempo, e assim criticá-lo, negá-lo, e transformá-lo. "Afinal, minha presença no mundo não é a de quem a ele se adapta, mas a de quem nele se insere. É a posição de quem luta para não se apenas objeto, mas sujeito também da história" (p.53). Com a eloquência que caracteriza a obra, Freire desenvolve a segunda parte ensinando a boniteza que há no ensinar que percebe a autonomia do ser do educando. Reflete sobre o bom-senso como uma postura sadia e necessária às relações entre educador e educando. Destarte, nos larga de mão-beijada a consciência da humildade e da tolerância, tão importantes para um processo de ensinar que seja produtivo, verdadeiro e militante. Oautor não deixa de lembrar que a luta por direitos e melhores condições de trabalho dos educadores faz-se indispensável a esta empreitada contra o fatalismo neoliberal. Acreditando neste enfrentamento, Freire, sempre foi coerente com suas convicções e sua prática. Postura esta que fica clara na leitura da obra e nos sinais de insignare que pontua para uma pedagogia da autonomia. "O mundo não é. O mundo está sendo" (p.74). 
Na terceira e última parte da obra o autor faz um granfinale ao nos lembrar de que não estamos reinventando a roda, estamos a falar de seres humanos, relações humanas. "No fundo, o essencial nas relações entre educador e educando, entre autoridade e liberdade, entre pais, mães, filhos e filhas é a reinvenção do ser humano no aprendizado de sue autonomia" (p.92). Seres humanos inacabados, inconformados, curiosos, apetentes por novidades. Logo, "não é possível exercer a atividade no magistério como se nada ocorresse conosco." (p.94). Nesse sentido, o autor insiste em apontar a importância política da educação como transformadora da sociedade. A educação como prática legítima de intervenção no mundo. Queira o professor ou não, progressista ou autoritário, sua marca vai ficar na vida do educando e na sua também. "A educação não vira política por causa da decisão deste ou daquele educador. Ela é política" (p.108). Se a educação é política e o "homem é um animal político", todos tem voz. Logo, devemos ouvi-los. Freire não deixa escapar este tão importante saber para a prática educativa. Lembra que saber escutar torna-nos iguais, gentis, humildes e o mais belo, um educador. "É preciso afirmar que ninguém pode ser humilde por puro formalismo, como se cumprisse mera obrigação burocrática" (p.118). Paulo Freire termina a obra com uma clareza inconfundível sobre a seriedade de como se deve tratar a educação; a importância do rigor cientifico nas abordagens, para assim poder o educador ser livre e feliz, completo, estimulado e estimulador. "Estou convencido, porém de que a rigorosidade, a séria disciplina intelectual, 0 exercício da curiosidade epistemológica não me fazem necessariamente um ser mal-amado, arrogante, cheio de mim mesmo" (p.143), apenas nos torna autônomos. 